\title{
A new species of sexually dimorphic Pareiorhaphis Miranda Ribeiro, 1918 (Siluriformes: Loricariidae) from the rio Doce basin, Brazil
}

\author{
Edson H. L. Pereira*, Fábio Vieira** and Roberto E. Reis*
}

Pareiorhaphis nasuta, a new neoplecostomine catfish of the family Loricariidae is described. The species was collected from headwaters of the rio Matipó, tributary of the upper rio Doce basin in State of Minas Gerais, Brazil. The new species is readily diagnosed from all remaining congeners by the longer snout and by the smaller orbital diameter. The new species is the first representative of the genus Pareiorhaphis discovered in the rio Doce basin, thus expanding its geographic distribution. A phylogenetic diagnosis for Pareiorhaphis is presented.

Pareiorhaphis nasuta, um novo cascudo neoplecostomíneo da família Loricariidae é descrito. Os exemplares foram capturados nas cabeceiras do rio Matipó, tributário do rio Doce no Estado de Minas Gerais, Brasil. A nova espécie é facilmente diagnosticada entre todos os demais congêneres pelo maior comprimento do focinho e pelo menor diâmetro orbital. Esta nova espécie representa o primeiro registro do gênero Pareiorhaphis na bacia do rio Doce, expandindo a sua distribuição geográfica. Uma diagnose filogenética é apresentada para Pareiorhaphis.

Key words: Freshwater, Taxonomy, Systematics, Neotropical, Catfish.

\section{Introduction}

Pareiorhaphis Miranda Ribeiro, 1918 is the most diverse genus in the subfamily Neoplecostominae, comprising 17 valid species (Pereira, 2005). These fishes are small to medium-sized suckermouth armored catfishes with maximum standard length between $34 \mathrm{~mm}$ (P. nudulus) and $116 \mathrm{~mm}$ (P. azygolechis). Pareiorhaphis was recently resurrected from the synonymy of Hemipsilichthys Eigenmann \& Eigenmann, 1889 by Pereira (2005), to accommodate several species previously assigned to the latter genus. That resurrection was based on the discovery that three species of Hemipsilichthys plus Delturus belong to a clade that is the sister-group to all remaining loricariids except Lithogenes, and was subsequently described as the subfamily Delturinae by Reis et al. (2006). A new phylogenetic diagnosis of Pareiorhaphis is presented below, based on our ongoing studies, and was used to allocate the new species in Pareiorhaphis.

Nuptial male Pareiorhaphis have similar sexual dimorphism characterized by a thickened pectoral-fin spine and hypertrophied odontodes (integumentary teeth) on the dorsal surface of the pectoral-fin spine and on the lateral margins of the head. Most species of Pareiorhaphis are distributed in the coastal basins of southern, southeastern, and northeastern Brazil, with highest species diversity observed in coastal rivers of Santa Catarina State, from the rio Araranguá basin north to the rio São João. One species, Pareiorhaphis regani was described from the rio Curicuriari, a tributary to the rio Negro in the Amazon basin. Recently, Pareiorhaphis parmula was described from the headwaters of the rio Iguaçu, in the rio Paraná basin, increasing the geographic distribution range of the genus. During the last five years, six new species have been described, which are currently assigned to Pareiorhaphis (Pereira \& Reis, 2002 and Pereira, 2005). This growth in the rate of species descriptions can be attributed to the increased interest of the taxonomists, but also to the exploration efforts in regions poorly sampled in the past. In recent fish collections made in headwater tributaries of the rio Doce basin, in Minas Gerais State, additional specimens of Pareiorhaphis were collected and discovered to belong to an undescribed species. The present work reports the first record of a Pareiorhaphis species in the rio Doce drainage and again expands the distribution of the genus.

\footnotetext{
*Laboratório de Ictiologia, Pontifícia Universidade Católica do Rio Grande do Sul, Av. Ipiranga 6681, 90619-900 Porto Alegre, RS, Brazil. edson.pereira@pucrs.br; reis@pucrs.br

**Agência Shopping Del Rey, Caixa Postal 4011, 31250-970 Belo Horizonte, MG, Brazil. riodocemg@ig.com.br
} 


\section{Material and Methods}

Institutional abbreviations are as listed in Reis et al. (2003) with the addition of MZUFV Museu de Zoologia João Moojen de Oliveira, Universidade Federal de Viçosa. All morphometric features were measured with digital calipers to the nearest 0.1 $\mathrm{mm}$ and were made from point to point under a stereomicroscope. Measurements of bilaterally symmetrical features were made in the left side of the body whenever possible. Body plate counts and nomenclature follow Schaefer (1997). Measurements include: (1) standard length (measured from the snout tip to the last plate in median series, but not including the horizontally elongate plate covering insertion of middle caudal-fin rays); (2) head length (measured from the snout tip to the end of parieto-supraoccipital bone); (3) predorsal length (measured from the snout tip to the dorsalfin origin); (4) postdorsal length (measured from end of dorsalfin base to the last plate in median series, but not including the horizontally elongate plate covering insertion of middle caudal-fin rays); (5) preanal length (measured from snout tip to the anal-fin origin); (6) preadipose length (measured from the snout tip to the adipose-fin spine insertion); (7) dorsal-fin spine length (measured from its origin to its distal tip); (8) anal-fin spine length (measured from its origin to its distal tip); (9) pectoral-fin spine length (measured from its origin to end of osseous spine, disregarding the fleshy tip); (10) ventral-fin spine length (measured from its origin to its distal tip); (11) upper caudal-fin ray (measured from its origin to its distal tip); (12) lower caudal-fin ray (measured from its origin to its distal tip); (13) adipose-fin spine length (measured dorsally from its origin to its distal tip); (14) adipose to caudal fin distance (measured from the adipose-fin origin to last plate in median series, not including the horizontally elongate plate covering insertion of the middle caudal fin rays); (15) trunk length (average of left and right distance from origin of pectoral-fin spine to origin of pelvic-fin spine); (16) abdominal length (measured from a line uniting both pelvic-fin origins to the origin of anal-fin); (17) cleithral width (measured transversally at widest point, in front of pectoral-fin origin); (18) body depth at dorsal-fin origin (measured at dorsal-fin origin); (19) body width at dorsal-fin origin (measured at the same point of measurement 18); (20) body width at anal-fin origin (measured at anal-fin origin); (21) caudal peduncle length (measured from anal-fin origin to last plate in median series, not including the horizontally elongate plate covering insertion of the middle caudal fin rays); (22) caudal peduncle depth (measured at point of shallowest depth of the caudal peduncle); (23) caudal peduncle width (measured at the same point of measurement 22); (24) snout length (measured from the snout tip to the anterior orbital margin); (25) orbital diameter (measured horizontally between anterior and posterior orbital margins); (26) interorbital width (measured horizontally between upper orbital margins); (27) head depth (measured at the central portion of the parieto-supraoccipital bone); (28) mandibular ramus (measured by pressing the calipers on the long axis of the dentary bone - presented as the average of left and right dentaries). Counts include: (29) premaxillary teeth (number of teeth per jaw ramus); (30) dentary teeth (number of teeth per jaw ramus); (31) plates in median series (counted on both sides); (32) plates at dorsalfin base (number of plates in dorsal series along the dorsalfin base); (33) plates between dorsal and adipose fins (number of plates in dorsal series between insertion of last branched dorsal-fin ray and origin of adipose-fin spine); (34) plates between adipose and caudal fins (number of plates in dorsal series from just posterior the adipose-fin membrane to the caudal fin); (35) plates at anal-fin base (number of plates in ventral series along the anal-fin base); (36) plates between anal and caudal fins (number of plates in ventral series between insertion of last branched anal-fin ray and caudal fin); (37) pre-adipose azygous plates (all unpaired plates preceding the insertion of the adipose-fin spine).

Standard length is expressed in millimeters while all other measurements are expresed as percents of standard length, except subunits of the head, which are expressed as percents of head length. In the list of type material museum abbreviation and catalog number come first, followed by the number of specimens in that lot, the number of specimens measured for the morphometric comparisons in parentheses, the range of standard length, locality, date of collection, and collectors. Abbreviations used are SL (standard length) and HL (head length). Comparative material includes the type specimens of all Pareiorhaphis species but $P$. regani.

Nuptial males of Pareiorhaphis are defined as specimens having the distinctive modifications that involves the shape of the pectoral-fin spine, and hypertrophied odontodes and fleshy lobes on lateral margins of head, although not necessarily being reproductively mature. The remaining specimens included in the list of material examined are a combination of female, male, and immature specimens of both sexes.

\section{Results}

\section{Pareiorhaphis Miranda Ribeiro, 1918}

Pareiorhaphis Miranda Ribeiro, 1918: 106. Type species: Hemipsilichthys calmoni (=Psilichthys cameroni Steindachner, 1907). Type species by subsequent designation by Regan (1920: 14). Gender: feminine. Subsequent type species designation by Gosline (1947: 102) of Hemipsilichthys duseni is invalid.

Diagnosis. Pareiorhaphis is diagnosed among loricariids by having the following synapomorphies. (1) Cheeks (postrostral and cheek plates) covered with hypertrophied odontodes in nuptial males. This character is shared with delturines, Isbrueckerichthys duseni, and some loricariines and hypostomines. (2) Opercle with hypertrophied odontodes in nuptial males. Present in all Pareiorhaphis and shared with Hemipsilichthys and some loricariines. (3) Exposed lateral process of cleithum with hypertrophied odontodes in nuptial males. Present in all Pareiorhaphis species and shared with 
Hemipsilichthys gobio and H. papillatus and some loricariines. (4) Lateroventral portion of preopercle deeply rugose due to the implantation of hypertrophied odontodes in nuptial males. Present in all Pareiorhaphis species and shared with $H$. gobio and $H$. papillatus. The characters shared with the groups above are most parsimoniously interpreted as independently derived according to the discussion of relationships in Armbruster (2004) and Reis et al. (2006).

The following characters are also useful to distinguish Pareiorhaphis species from the remaining neoplecostomines. Abdomen naked or with small embedded platelets and lower lip without a series of distinct papillae behind the dentaries ( $v s$ abdomen with plates forming a central polygonal path and lower lip with a series of distinct papillae behind the dentaries in Neoplecostomus); infraorbital series of plates forming the lateral edge on the nasal opening and dorsal-fin spinelet usually present ( $v s$ infraorbital series of plates not forming the lateral edge of the nasal opening and dorsal-fin spinelet absent in Isbrueckerichthys); adipose fin present ( $v s$ absent in Pareiorhina); tooth series in dentary straight or slightly curved and odontodes on ventral surface of pelvicfin spine aligned with the spine axis ( $v s$ tooth series in dentary approximately U-shaped and odontodes on ventral surface of pelvic-fin spine turned medially in Kronichthys).

\section{Pareiorhaphis nasuta, new species}

Fig. 1, Table 1

Holotype. MCP 41764, 78.6 mm SL, male; Brazil: Minas Gerais: Abre Campo: District of Granada: ribeirão Areia Branca, tributary to the hydroelectric dam Túlio Cordeiro de Mello, rio Matipó basin, rio Doce drainage, $20^{\circ} 11^{\prime} 17^{\prime \prime S ~} 42^{\circ} 22$ '27"W, 9 Oct 2004, E. H. L. Pereira, R. E. Reis \& P. Lehmann.

Paratypes. Brazil: Minas Gerais: rio Doce drainage: MCP 37176 , $10+2$ c\&s (9) 25.1-78.6 mm SL; collected with the holotype. MCP 38809, 11 (7) 45.3-94.7 mm SL; rio Matipó, Distrito de Granada, Abre Campo, 20¹1'00"S 42²3'00"W, 17-20 Aug 2002, F. Vieira. MCP 38807, 3 (2) 39.8-63.4 mm SL; ribeirão Areia Branca, tributary to rio Matipó, Abre Campo, 20¹1'15"S 42²2'26"W, 29 Jul 2004, F. Vieira. MCP 38808, $10+1$ c\&s (6) 50.2-93.7 mm SL; ANSP 187153, 2 (2) 67.9-87.3 mm SL; and MZUFV 2567, 3 (2) 65.4-84.1 mm SL; rio Matipó at Raul Soares, $20^{\circ} 07^{\prime} 23$ "S 42²4'51"W, 1997, J. A. Dergam.

Diagnosis. Pareiorhaphis nasuta is distinguished from all congeners by the longer snout (71.1-75.6 vs 52.8-69.9\% HL). Additionally, the smaller orbital diameter (8.6-11.3 vs 11.7-18.8\% HL) further distinguishes $P$. nasuta from most other Pareiorhaphis species, except for $P$. garbei, $P$. vestigipinnis, P. cerosus, and P. splendens. Pareiorhaphis nasuta is further distinguished from $P$. garbei by having bifid teeth, with a small lateral cusp in both dentary and premaxilla ( $v s$ simple teeth, without lateral cusp in both dentary and premaxilla); from $P$. vestigipinnis by having an adipose fin ( $v s$ adipose fin absent); from $P$. cerosus by having one to three preadipose azygous plates ( $v s$ three to five plates); and from $P$. splendens by the longer pelvic-fin spine (19.4-23.4 vs 12.6-19.1\% SL).
Description. Counts and proportional measurements in Table 1. Standard length of measured specimens 55.5-94.7 mm SL. See Fig. 1 for general body aspect. Body elongate and moderately depressed, progressively narrowing from cleithrum to end of caudal peduncle. Dorsal profile of body gently convex, rising from snout tip to origin of dorsal fin and then descending to end of caudal peduncle. Greatest body depth at dorsal-fin origin. Least body depth at shallowest part of caudal peduncle. Trunk and caudal peduncle mostly oval in cross-section, slightly flattened ventrally and more compressed caudally. Lateral-line canal in median series complete, pored tube visible from compound pterotic to caudal-fin base. Ventral profile almost straight between snout tip and pelvic girdle, slightly elevating posteriorly along anal-fin base, almost straight along caudal peduncle. Dorsal surface of body covered by plates except for small naked area around dorsalfin base. Ventral surface of head, portion from pelvic-fin insertion to anal-fin origin, and portion around anal-fin totally

Table 1. Morphometric and meristic data of Pareiorhaphis nasuta. Values are given as percent of standard length or head length. $\mathrm{SD}=$ standard deviation, $\mathrm{n}=$ number of specimens, $\mathrm{H}=$ holotype.

\begin{tabular}{|c|c|c|c|c|c|c|}
\hline & \multicolumn{6}{|c|}{ Types } \\
\hline & $\mathrm{H}$ & $\mathrm{n}$ & Low & High & Mean & $\mathrm{SD}$ \\
\hline Standard length (mm) & 78.6 & 29 & 55.5 & 94.7 & 74.4 & \\
\hline \multicolumn{7}{|c|}{ Percents of Standard Length } \\
\hline Head length & 34.3 & 29 & 32.9 & 37.1 & 35.0 & 0.87 \\
\hline Predorsal length & 44.2 & 29 & 42.6 & 46.5 & 44.5 & 1.08 \\
\hline Postdorsal length & 39.9 & 29 & 37.2 & 42.0 & 39.6 & 1.11 \\
\hline Preanal length & 66.2 & 29 & 65.3 & 69.8 & 67.4 & 1.24 \\
\hline Preadipose length & 79.2 & 29 & 67.2 & 81.2 & 78.1 & 2.51 \\
\hline Dorsal-fin spine length & 20.4 & 29 & 18.1 & 21.8 & 19.4 & 0.99 \\
\hline Anal-fin spine length & 15.9 & 29 & 13.2 & 17.1 & 14.7 & 1.09 \\
\hline Pectoral-fin spine length & 17.4 & 28 & 14.6 & 21.3 & 17.5 & 1.47 \\
\hline Ventral-fin spine length & 22.2 & 29 & 19.4 & 23.4 & 21.4 & 1.06 \\
\hline Upper caudal-fin ray & 23.6 & 25 & 20.1 & 25.1 & 22.5 & 1.19 \\
\hline Lower caudal-fin ray & 25.5 & 28 & 21.1 & 25.7 & 24.2 & 1.24 \\
\hline Adipose-fin spine length & 10.3 & 29 & 7.9 & 10.6 & 9.2 & 0.77 \\
\hline Adipose to caudal fin distance & 20.3 & 29 & 16.7 & 23.0 & 21.0 & 1.27 \\
\hline Trunk length & 15.9 & 29 & 15.1 & 18.5 & 16.9 & 0.82 \\
\hline Abdominal length & 22.2 & 27 & 21.5 & 24.5 & 23.1 & 0.80 \\
\hline Cleithral width & 28.1 & 28 & 26.7 & 30.1 & 28.5 & 0.80 \\
\hline Body depth at dorsal-fin origin & 20.2 & 29 & 17.0 & 21.6 & 19.6 & 1.25 \\
\hline Body width at dorsal-fin origin & 23.1 & 29 & 18.3 & 25.3 & 22.5 & 1.32 \\
\hline Body width at anal-fin origin & 14.3 & 29 & 11.2 & 17.1 & 14.2 & 1.17 \\
\hline Caudal peduncle length & 32.2 & 29 & 30.5 & 35.1 & 33.0 & 1.16 \\
\hline Caudal peduncle depth & 9.6 & 29 & 8.2 & 10.2 & 9.3 & 0.49 \\
\hline Caudal peduncle width & 5.2 & 29 & 4.7 & 6.7 & 5.5 & 0.46 \\
\hline \multicolumn{7}{|c|}{ Percents of Head Length } \\
\hline Snout length & 74.9 & 29 & 71.1 & 75.6 & 73.4 & 1.11 \\
\hline Orbital diameter & 9.6 & 29 & 8.6 & 11.3 & 9.8 & 0.79 \\
\hline Interorbital width & 28.9 & 29 & 26.5 & 29.9 & 28.1 & 1.00 \\
\hline Head depth & 49.0 & 29 & 44.4 & 55.0 & 49.0 & 2.59 \\
\hline Mandibular ramus & 24.0 & 29 & 21.7 & 26.0 & 24.0 & 1.10 \\
\hline \multicolumn{7}{|c|}{ Counts } \\
\hline Premaxillary teeth & $72 / 73$ & 29 & 51 & 82 & 65.2 & \\
\hline Dentary teeth & $74 / 77$ & 28 & 46 & 78 & 63.6 & \\
\hline Plates in median lateral series & 25 & 29 & 24 & 27 & 24.9 & \\
\hline Plates at dorsal-fin base & 5 & 29 & 5 & 6 & 5.4 & \\
\hline Plates between dorsal and adipose & 7 & 29 & 6 & 7 & 6.8 & \\
\hline Plates between adipose and caudal & 4 & 29 & 3 & 5 & 4.0 & \\
\hline Plates at anal-fin base & 3 & 29 & 2 & 4 & 3.0 & \\
\hline Plates between anal and caudal & 11 & 29 & 10 & 11 & 10.5 & \\
\hline Pre-adipose azygous plates & 2 & 29 & 1 & 3 & 1.8 & \\
\hline
\end{tabular}


naked. Abdomen almost completely naked, except for one to four small platelets on each side just posterior to gill opening, sometimes absent in specimens smaller than $50 \mathrm{~mm}$ SL.

Head broad and moderately depressed. Dorsal profile of head broadly round in dorsal view; females and juveniles more slender. Interorbital space slightly concave. Three slightly elevated ridges between orbits and snout tip. Lateral ridges from middle of snout to upper margins of orbits more prominent. These ridges ornamented with short hypertrophied odontodes in nuptial males. Lateral margin of head covered with minute odontodes. Snout gently convex in lateral profile; snout tip with ovoid area of naked skin. Nuptial males with well-developed soft fleshy lobes extending along lateral portion of head. Soft fleshy area ornamented with short hypertrophied odontodes, approximately perpendicular to body axis. Eye small, dorsolaterally placed; orbit diameter $8.6-11.3 \%$ of head length. Iris operculum small or absent. Nares ovoid, slightly longer than wide, positioned midway between snout tip and anterior orbit margin. Oral disk circular. Lips roundish and well-developed, occupying most of ventral surface of head. Lower lip almost reaching pectoral girdle, densely covered by minute papillae. Papillae surrounded by naked areas, decreasing in size towards edge. Posterior edge slightly fringed. Maxillary barbel short and united to lip by membrane basally, free distally. Both premaxillae and dentaries angled at approximately $120^{\circ}$, with mesial ends slightly curved

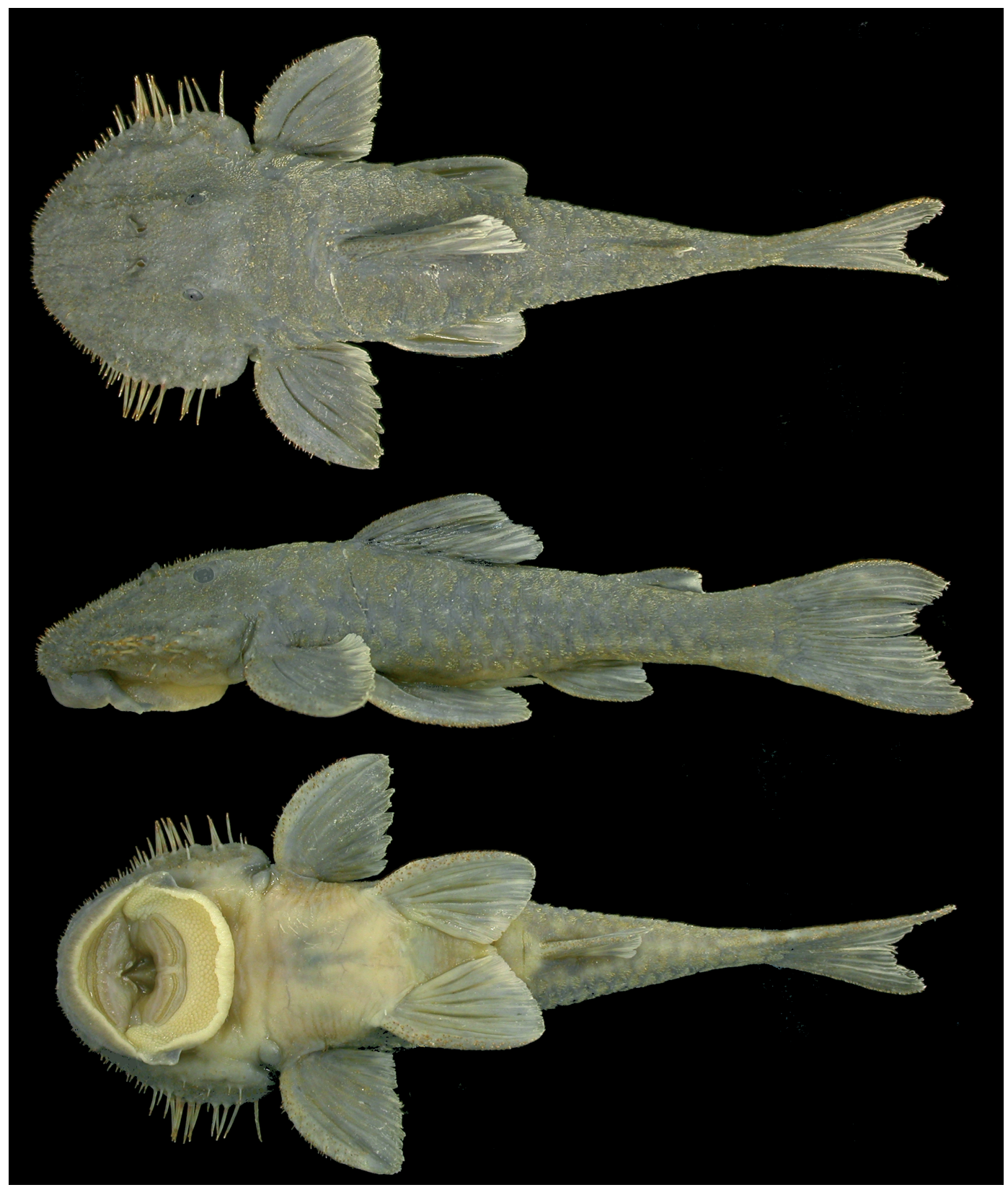

Fig. 1. Pareiorhaphis nasuta, holotype, male, MCP 41764, $78.6 \mathrm{~mm}$ SL. Brazil: Minas Gerais, ribeirão Areia Branca, tributary to the upper rio Matipó, rio Doce drainage. 
inwards. Teeth slender, asymmetrically bifid, medial cusp slightly curved inwards. Lateral cusp minute and pointed, never reaching half length of medial cusp.

Dorsal fin originating on vertical line passing through pelvic-fin origin. Dorsal fin short, not reaching preadipose azygous plates when depressed. Nuchal plate exposed, not covered by skin. Dorsal-fin spinelet present but dorsal-fin locking mechanism non-functional. Dorsal-fin spinelet oval and wider than dorsal-fin spine base. Dorsal-fin spine moderately flexible, followed by seven branched rays. Adipose fin with well-ossified leading spine bearing odontodes. Adipose fin preceded by one or two (rarely three) median unpaired preadipose azygous plate. Pectoral fin moderate in size, with curved and depressed spine, covered by minute odontodes in immature males and females. Nuptial males with pectoral fin spine bearing straight and delicate hypertrophied odontodes on outer and ventral faces. Six branched rays, first and second as long as spine. Subsequent branched rays reduced gradually in size. Posterior margin of pectoral fin straight to slightly round, overlapping pelvic-fin origin when adpressed. Pelvic fin with one spine and five branched rays, not reaching or almost reaching to anal-fin origin when adpressed. Pelvic-fin spine depressed, covered with minute odontodes ventrally and laterally; dermal flap on its dorsal surface present and developed, extending to tip of spine. Pelvic-fin flap distinctly higher near fin base. Anal fin with one unbranched and five branched rays; passing adipose-fin origin when adpressed. Caudal-fin forked; lower lobe slightly longer than upper; 14 branched rays. Upper caudal-fin lobe with five and lower lobe with four ventral plate-like procurrent rays, posteriormost elongate. Odontodes on principal and procurrent rays small and irregurlarly arranged.

Coloration in alcohol. Ground color of dorsal surface of head and body grayish or sometimes light brown (dark gray in living specimens), whitish or light yellowish ventrally. Dorsum and flanks mostly plain, neither males nor females with small dark spots or saddles on dorsum and flank. Spines and branched rays of dorsal, anal, and caudal fins plain grayish. Caudal fin sometimes with one or two diffuse narrow bands. Paired fins uniformly grayish, occasionally posterior margin of pectoral fin slightly whitish. Spines of pectoral and pelvic fins uniformly grayish dorsally and ventrally. Fin membranes hyaline. Ventral margin of head, outer portion of upper lip, and ventral portion of caudal peduncle dusky.

Distribution. Pareiorhaphis nasuta is known from three localities in Minas Gerais State, the type-locality in the ribeirão Areia Branca, tributary to the rio Matipó, and two sites in the rio Matipó itself. These sites are located in the upper rio Doce basin and are separated by a maximum of $14 \mathrm{~km}$.

Ecology. The ribeirão Areia Branca, type locality of Pareiorhaphis nasuta, is a small (about three to four meters wide), shallow river with very clear, transparent water, and slow to moderate current. The bottom has rocks, loose stones, and sometimes gravel. Grass or other vegetation is present on the margins. Rapids and small pools were found along the stream, but specimens were captured in areas of rapids among loose stones and pebbles. Nuptial males and larger specimens are usually captured among the larger stones and on the stronger current.

Two other populations were sampled on the main channel of the rio Matipó, at Raul Soares (MCP 38808, ANSP 187153, and MZUFV 2567) in 1997 by Jorge Dergam and at Abre Campo (MCP 38809) in 2002 by F. Vieira. The river was 20 to 25 meters wide, one to two meters deep, and with strong rapids. The water was nearly transparent and slightly black, with fast current. The bottom consisted mostly of large stones and boulders. In this area, the new species was syntopic with Astyanax cf. taeniatus, Hypostomus affinis, Harttia sp., Neoplecostomus sp., Trichomycterus spp., Rhamdia quelen, and Geophagus brasiliensis.

Sexual dimorphism. As usual for Pareiorhaphis (e.g. Reis \& Pereira, 1999, fig. 2; Pereira \& Reis, 2002, fig. 6; Pereira, 2005, fig. 1), nuptial males of Pareiorhaphis nasuta have a slightly thickened pectoral-fin spine with somewhat enlarged odontodes and hypertrophied odontodes on the lateral margins of head. Odontodes also occur in females and juveniles, but are much smaller. Also, nuptial males of most species are distinguished from females by having a dermal flap on the dorsal surface of the pelvic-fin spine, which is absent or very reduced in females. In addition to that, and contrary to most other Pareiorhaphis species, fully developed males of the P. nasuta have a well-developed fleshy flap along the entire length of the posterodorsal margin of the pectoral-fin spine.

Etymology. The specific epithet of Pareiorhaphis nasuta is from the Latin nasutus, meaning long-nosed, in allusion to the long snout, diagnostic of this species. An adjective.

\section{Discussion}

The diagnosis of Pareiorhaphis presented above is based on our ongoing phylogenetic studies of the neoplecostomines which encompass most of the neoplecostomine species, including several undescribed, and will be published elsewhere.

Pareiorhaphis is distinguished from Isbrueckerichthys by having the infraorbital series of plates forming the lateral edge on the nasal opening and by having a predorsal spinelet. Pereira (2005) described a new species of Pareiorhaphis, $P$. parmula, that has one, or rarely two, platelets on each side of the pectoral girdle, just posterior to the gill openings. Pareiorhaphis nasuta shares this feature with $P$. parmula and have two or three small plates in the same region. Both $P$. nasuta and $P$. parmula can be easly distinguished from Isbrueckerichthys by lacking plates on the central region of the abdomen, as seen in Isbrueckerichthys and by having a predorsal spinelet. Furthermore, P. nasuta can be 
distinguished from P. parmula by the smaller orbital diameter (8.6-11.3 vs 12.7-15.9\% HL). Finally, the most distinctive feature of $P$. nasuta is the larger snout length that diagnoses it from all remaining congeners (71.1-75.6 vs 52.8-69.9\% HL).

The distribution of Pareiorhaphis is herein extended to include the headwater streams of the rio Doce drainage (Fig. 2 ), suggesting that the species-level diversity among catfishes of the genus Pareiorhaphis is significantly higher than as previously defined by Pereira \& Reis (2002) and Pereira (2005). The occurrence of $P$. nasuta in the rio Doce basin suggests that the distribution of the genus may be still broader than is presently known.

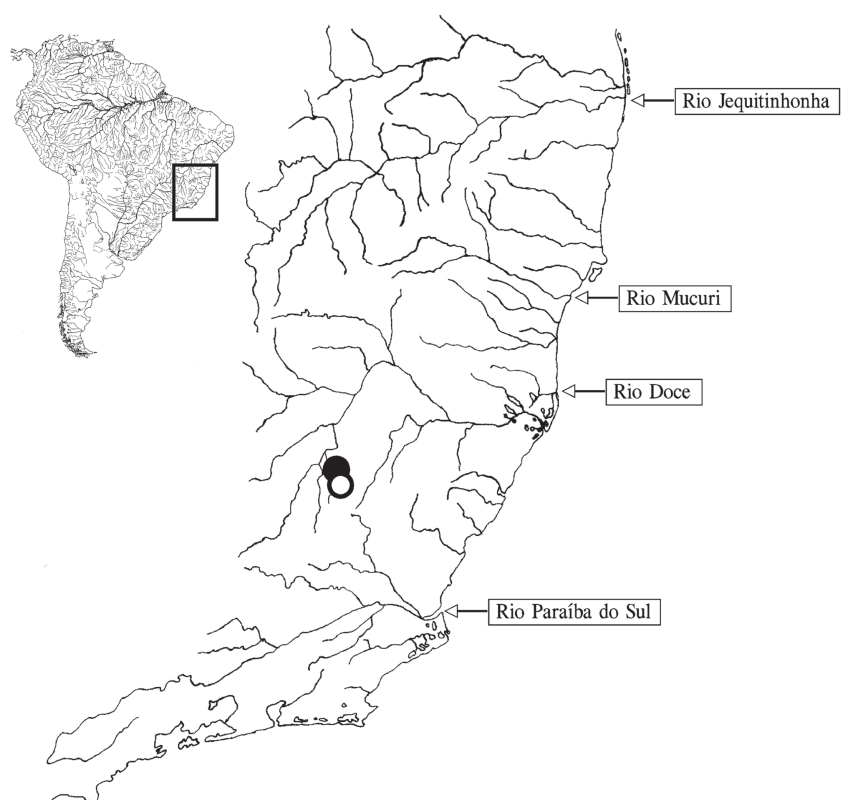

Fig. 2. Map of eastern Brazil showing geographic distribution of Pareiorhaphis nasuta. Open symbol represents type-locality.

Comparative material examined: All from Brazil (in addition to that listed in Pereira \& Reis, 2002) is: Hemipsilichthys nimius: MCP 33049, $105.1 \mathrm{~mm}$ SL (holotype), rio Carrasquinho below the Cachoeira do Tobogã, Parati, Rio de Janeiro. MCP 31990, 11, 45.7$98.1 \mathrm{~mm}$ SL (paratypes), collected with the holotype. Isbrueckerichthys epakmos: MZUSP 79804, 103.1 mm SL (holotype); rio Verde at Piúva, on road to Rio Verde, Tapiraí, São Paulo. MCP 28276, 63, 39.5-83.3 mm SL (paratypes), rio Coruja, tributary to rio Juquiá, on road from Tapiraí to Juquiá near Cachoeira do Chá, São Paulo. Kronichthys subteres: MCP 20150, 32, 38.1$76.8 \mathrm{~mm}$ SL, córrego Areias, ca $1 \mathrm{~km}$ SE from Bairro da Serra, Iporanga, São Paulo. Neoplecostomus microps: MCP 20069, 4, 47.1$89.3 \mathrm{~mm} \mathrm{SL}$, ribeirão Benfica at Benfica, ca $1 \mathrm{~km}$ of Piquete, São Paulo. MCP 20071, 13, 45.1-98.3 mm SL, ribeirão Macacos at Bairro dos Macacos, Silveiras. Pareiorhaphis parmula: MCP 35826 , $93.3 \mathrm{~mm} \mathrm{SL}$, (holotype), rio dos Patos, tributary to rio da Várzea on road PR-427 from Lapa to Campo Tenente, Paraná. MCP 35827 , $59+2$ c\&s, 45.7-94.5 mm SL, collected with the holotype. Pareiorhina carrancas: LIRP 2280, $1+1$ c\&s, 35.8-36.9 mm SL (paratypes), córrego Debaixo da Serra, Carrancas, Minas Gerais. Pareiorhina rudolphi: MCP 18052, 23 + 1 c\&s, 30.4-49.3 mm SL, creek tributary of rio Piquete at Benfica, São Paulo.

\section{Acknowledgements}

The manuscript benefited from the review of two anonymous reviewers, to which we are very thankful. Specimens were collected under permits from the Instituto Estadual de Florestas (IEF-MG) issued to F. Vieira and from IBAMA, issued to R. Reis. Fieldwork associated with this study was supported by the All Catfish Species Inventory (NSF DEB-0315963), and the CAT-LEO Energia S.A.(F. Vieira), to which we are much indebted. EHLP is partially financed by a doctoral fellowship from CAPES and RER is partially financed by CNPq (process \# 301748/2004-7).

\section{Literature Cited}

Armbruster, J. W. 2004. Phylogenetic relationships of the suckermouth armoured catfishes (Loricariidae) with emphasis on the Hypostominae and the Ancistrinae. Zoological Journal of the Linnean Society, 141: 1-80.

Gosline, W. A. 1947. Contributions to the classification of the loricariid catfishes. Arquivos do Museu Nacional do Rio de Janeiro, 41: 79-134.

Pereira, E. H. L. 2005. Resurrection of Pareiorhaphis Miranda Ribeiro, 1918 (Teleostei: Siluriformes: Loricariidae), and description of a new species from the rio Iguaçu basin, Brazil. Neotropical Ichthyology, 3(2): 271-276.

Pereira, E. H. L. \& R. E. Reis. 2002. Revision of the loricariid genera Hemipsilichthys and Isbrueckerichthys (Teleostei: Siluriformes), with descriptions of five new species of Hemipsilichthys. Ichthyological Exploration of Freshwaters, 13: 97-146.

Regan, C. T. 1920. XV - Pisces. Zoological Records [1918], 55:1-19.

Reis, R. E. \& E. H. L. Pereira. 1999. Hemipsilichthys nudulus, a new uniquely plated species of loricariid from the rio Araranguá basin in southern Santa Catarina State, Brazil (Teleostei, Siluriformes). Icththyological Exploration of Freshwaters, 10(1): 45-51.

Reis, R. E., S. O. Kullander, \& C. J. Ferraris, Jr. [Eds]. 2003. Check list of the freshwater fishes of South and Central America. Edipucrs, Porto Alegre, 729p.

Reis, R. E., E. H. L. Pereira \& J. W. Armbruster. 2006. Delturinae, a new loricariid catfish subfamily (Teleostei, Siluriformes), with a revision of Delturus and Hemipsilichthys. Zoological Journal of the Linnean Society, 147: 277-299.

Schaefer, S. A. 1997. The neotropical cascudinhos: systematics and biogeography of the Otocinclus catfishes (Siluriformes: Loricariidae). Proceedings of the Academy of Natural Sciences of Philadelphia, 148: 1-120. 